\title{
A quantum dot fluorescent microsphere based immunochromatographic strip for detection of brucellosis
}

\author{
Yufang Kong ${ }^{1 \dagger}$, Huiyu Wang ${ }^{1 \dagger}$, Shaoqiang Wu', Jizhou Lv', Lin Mei ${ }^{1}$, Huifang Zhou², Xiangmei Lin ${ }^{1 *}$ and \\ Xueqing $\operatorname{Han}^{1 *}$ (D)
}

\begin{abstract}
Background: Brucellosis is a serious zoonosis disease that frequently causes significant economic loss in animal husbandry and threatens human health. Therefore, we established a rapid, accurate, simple and sensitive fluorescent immunochromatographic strip test (ICST) based on quantum dots (QDs) for detection the antibodies of Brucella infection animals serum.

Results: The test strips were successfully prepared by quantum dot fluorescent microspheres (QDFM) as tracers, which were covalently coupled to an outer membrane protein of Brucella OMP22. The outer membrane protein OMP28 and monoclonal antibodies of OMP22 were separately dispensed onto a nitrocellulose membrane as test and quality control lines, respectively. The critical threshold for determining negative or positive through the ratio of the fluorescent signal of the test line and the control line $\left(H_{T} / H_{C}\right)$ is 0.0492 . The repeatability was excellent with an overall average CV of 8.78\%. Under optimum conditions, the limit of detection was $1.05 \mathrm{ng} / \mathrm{mL}$ (1:512 dilution). With regard to the detection of brucellosis in 150 clinical samples, the total coincidence rate of ICST and Rose Bengal plate test (RBPT) was 97.3\%, the coincidence rate of positive samples was $98.8 \%$, the coincidence rate of negative samples was $95.3 \%$, the sensitivity of RBPT is 1:32, and no cross reaction with the sera of other related diseases was observed.
\end{abstract}

Conclusion: In our present study, the QDFM has promising application for on-site screening of brucellosis owing to its high detection speed, high sensitivity, high specificity and low cost.

Keywords: Brucellosis, Quantum dots fluorescent microspheres, Immunochromatographic strip test

\section{Background}

Brucellosis is a highly infectious zoonosis and poses serious threats to human health [1]. Brucella can infect humans in many ways, for example, contact with infected livestock and wildlife, and consumption of meat products and milk products infected with Brucella or incidental exposure to live attenuated vaccine and so on

\footnotetext{
*Correspondence: linxm@caiq.org.cn; 1422355351@qq.com

${ }^{\dagger}$ Yufang Kong and Huiyu Wang contributed equally to this work.

Institute of Animal Inspection and Quarantine Chinese Academy of Inspection and Quarantine 100176 Beijing China

Full list of author information is available at the end of the article
}

[2-5]. Brucella contributes to abortions, infertility, placenta retention, still birth or weak offspring, and poor reproductive performance of animals, which results in huge economic losses for livestock farmers [6]. Currently, there is no effective method to prevent this disease, therefore, early diagnosis and monitoring are very essential.

Traditional detection methods of Brucella are pathogen isolation identification, serological diagnosis and molecular biology, which have a few defects [7]. The pathogen isolation identification method produces

(c) The Author(s). 2021 Open Access This article is licensed under a Creative Commons Attribution 4.0 International License, which permits use, sharing, adaptation, distribution and reproduction in any medium or format, as long as you give appropriate credit to the original author(s) and the source, provide a link to the Creative Commons licence, and indicate if changes were made. The images or other third party material in this article are included in the article's Creative Commons licence, unless indicated otherwise in a credit line to the material. If material is not included in the article's Creative Commons licence and your intended use is not permitted by statutory regulation or exceeds the permitted use, you will need to obtain permission directly from the copyright holder. To view a copy of this licence, visit http://creativecommons.org/licenses/by/4.0/. The Creative Commons Public Domain Dedication waiver (http://creativecommons.org/publicdomain/zero/1.0/) applies to the data made available in this article, unless otherwise stated in a credit line to the data. 
qualitative and quantitative results, but the method requires strict laboratory conditions and poses potential exposure risk to performers. The serological diagnostic methods including the Rose Bengal plate test (RBPT), standard tube agglutination test (SAT) and enzymelinked immunosorbent assay (ELISA) need the whole cell or whole smooth lipopolysaccharides (S-LPS) as the antigen. Moreover, these methods may cause false positives and cross-reactivity with other Gram-negative bacteria [8-10]. Molecular biology methods such as polymerase chain reaction (PCR) [11], real time PCR (qPCR) [12], provide qualitative and quantitative results with good accuracy and sensitivity. However, these methods require expensive instruments and professional operators. They are time consuming and easy to produce aerosol pollution [13]. Therefore, it is extremely important to establish a rapid, accurate and sensitive method to detect brucellosis [7].

In previous studies, the colloidal gold test strip method showed low sensitivity and species limitation. Dmitriy et al established Brucella colloidal gold antibody test strip can only detect bovine serum and the serum dilution limit of detection was only 1:250 [14]. Recently, a new labelled and more sensitive method was developed with fluorescent microspheres $[15,16]$. Therefore, in this study, we developed a diagnostic for brucellosis by immunochromatography labeled with QDFM.

\section{Results}

\section{Optimization of the coating concentration for the NC membrane}

The optimal coating concentration of the test line and control line were selected as $1 \mathrm{mg} / \mathrm{mL}$ and $0.5 \mathrm{mg} / \mathrm{L}$, respectively. As shown in Fig. 1, there was good

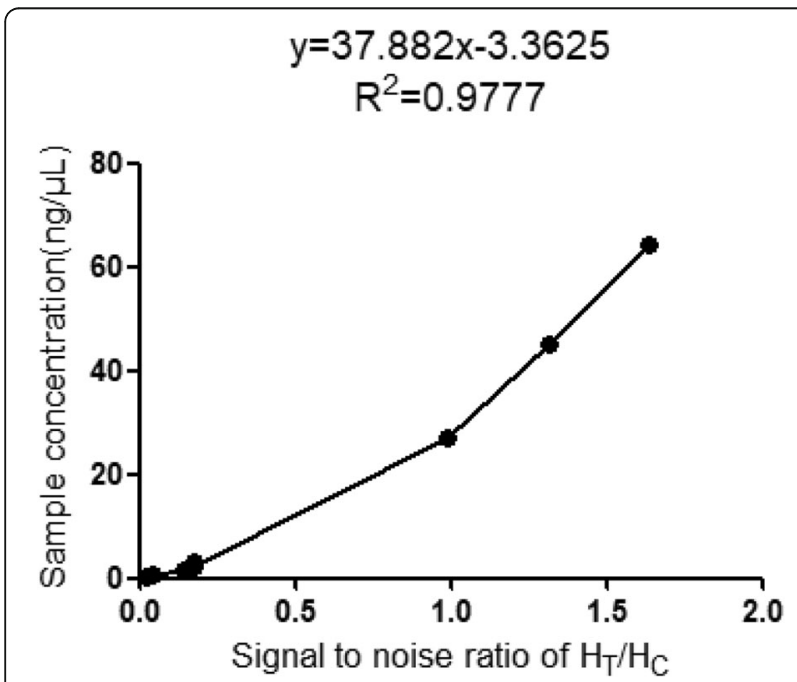

Fig. 1 Optimization of the coating concentration for the NC membrane correlation between $\mathrm{H}_{\mathrm{T}} / \mathrm{H}_{\mathrm{C}}(\mathrm{x})$ and the sample concentration $(y)$. The linear regression equation was $y=$ $37.882 \mathrm{x}-3.3625$ and the correlation coefficient was 0.9777 , indicating the feasibility of ICST for detecting brucellosis.

\section{Limit of detection}

The standard curve was established with serial 2-fold dilutions of Brucella positive serum from 1:4 to 1:1024, which were detected by. As shown in Fig. 2, the results can be read with naked eyes using a UV lamp and the fluorescent intensity of the test line gradually decreased. For low-antibody samples, the fluorescence intensity of the test line was weaker than the control line. At a dilution of 1:512, the fluorescence intensity was weakened, and the limit of detection was $1.05 \mathrm{ng} / \mathrm{mL}$. The fluorescent line disappears at a dilution of 1:1024. As shown in Table 1, these values can also be accurately detected by a fluorescence reader.

\section{Threshold and specificity test}

To determine the threshold, 50 healthy serum samples were tested by the ICST and their results suggested that the ICST threshold is 0.0492 . The $\mathrm{H}_{\mathrm{T}} / \mathrm{H}_{\mathrm{C}}$ value $\geq 0.0492$ (Table 2) indicated a positive assay of the ICST. The brucellosis samples displayed $\mathrm{H}_{\mathrm{T}} / \mathrm{H}_{\mathrm{C}}$ values greater than the threshold, indicating the positive results. The Y.enterocolitica O:9, E.coli O:157, Salmonella Dublin samples all displayed $\mathrm{H}_{\mathrm{T}} / \mathrm{H}_{\mathrm{C}}$ values less than the threshold, indicating the negative results and there was no cross reaction with the sera of other diseases (Table 3).

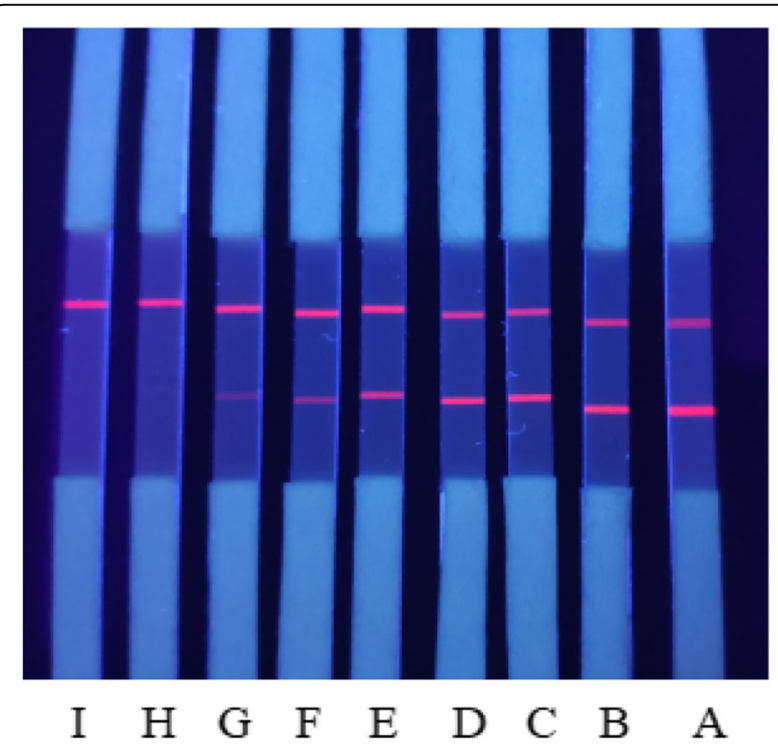

Fig. 2 The extreme detection limit of ICST for Brucella standard positive serum 
Table 1 Sensitivity assay of ICST testing of brucellosis

\begin{tabular}{llll}
\hline Dilution & $\mathbf{H}_{\mathbf{T}}$ & $\mathbf{H}_{\mathbf{C}}$ & $\mathbf{H}_{\mathrm{T}} / \mathbf{H}_{\mathbf{C}}$ \\
\hline $1: 4$ & 65,376 & 12,324 & 5.3048 \\
$1: 8$ & 56,124 & 13,632 & 4.1171 \\
$1: 16$ & 55,735 & 18,346 & 3.0380 \\
$1: 32$ & 47,775 & 20,434 & 2.3380 \\
$1: 64$ & 34,152 & 33,784 & 1.0109 \\
$1: 128$ & 26,789 & 31,892 & 0.8400 \\
$1: 256$ & 16,995 & 31,145 & 0.5457 \\
$1: 512$ & 8667 & 31,972 & 0.2711 \\
$1: 1024$ & 56 & 32,754 & 0.0017 \\
\hline
\end{tabular}

\section{Detection of brucellosis in clinical samples using ICST and} RBPT

The results of 150 samples were detected by the Fluorescence Reader. The coincidence rate was calculated by comparing with RBPT results. As shown in Table 4, the total coincidence rate of ICST and RBPT was $97.3 \%$ $[(85+61) / 150]$. Compared with RBPT, the positive coincidence rate of ICST was $98.8 \%[85 /(85+1)]$ and the negative coincidence rate of ICST was 95.3\% [61/(61+ $3)$ ]. As shown in Table 5, the sensitivity of RBPT is 1:32.

\section{Repeatability assay of the ICST for brucellosis}

The results showed that the ICST maximum CV value of all samples was $8.78 \%$, and the average value was $6.16 \%$. All the CV values of the above results are less than $10 \%$, indicating that the diagnostic procedures for brucellosis based on QDFM detection technology was repeatable (Table 6).

Table 2 The threshold assay of ICST with 50 healthy Brucella negative serum samples from bovine and sheep

\begin{tabular}{lccccc}
\hline Samples & $\mathbf{H}_{\mathbf{T}} / \mathbf{H}_{\mathbf{C}}$ & & & & \\
\hline & 0.0154 & 0.0004 & 0.0156 & 0.0151 & 0.0145 \\
& 0.0123 & 0.0269 & 0.0287 & 0.0269 & 0.0238 \\
& 0.0208 & 0.0212 & 0.0260 & 0.0332 & 0.0127 \\
& 0.0143 & 0.0037 & 0.0101 & 0.0414 & 0.0011 \\
Negative serum samples & 0.0187 & 0.0116 & 0.0070 & 0.0303 & 0.0123 \\
& 0.0362 & 0.0312 & 0.0109 & 0.0116 & 0.0103 \\
& 0.0244 & 0.0128 & 0.0125 & 0.0117 & 0.0201 \\
& 0.0316 & 0.0146 & 0.0281 & 0.0219 & 0.0018 \\
& 0.0151 & 0.0267 & 0.00148 & 0.0327 & 0.0333 \\
& 0.0007 & 0.0139 & 0.0044 & 0.0312 & 0.0031 \\
& Mean $=0.0177$ & & & \\
& Standard deviation $=0.0105$ & & \\
Threshold = 0.0492 & & & \\
\hline
\end{tabular}

Table 3 Specificity of the ICST for brucellosis

\begin{tabular}{lllll}
\hline Samples & $\mathbf{H}_{\mathbf{T}}$ & $\mathbf{H}_{\mathbf{C}}$ & $\mathbf{H}_{\mathbf{T}} / \mathbf{H}_{\mathbf{C}}$ & Result \\
\hline Brucellosis & 54,654 & 12,350 & 4.4254 & $(+)$ \\
Y.enterocolitica O:9 & 1196 & 32,035 & 0.0373 & $(-)$ \\
& 1023 & 31,989 & 0.0320 & $(-)$ \\
E.coli O:157 & 1325 & 30,425 & 0.0435 & $(-)$ \\
& 1146 & 32,147 & 0.0356 & $(-)$ \\
& 1158 & 32,201 & 0.0360 & $(-)$ \\
& 1123 & 31,987 & 0.0351 & $(-)$ \\
Salmonella Dublin & 1427 & 31,043 & 0.0460 & $(-)$ \\
& 1277 & 32,176 & 0.0400 & $(-)$ \\
\hline
\end{tabular}

\section{Discussion}

At present, it has been more than 100 years to develop effective methods for diagnosis of brucellosis, but brucellosis is still a recurring disease and is prevalent again in many parts around the world [17]. Brucella infections are easily transmitted to humans, causing acute febrile illness -- undulant fever -- which may progress to a more chronic form and can also produce serious complications affecting the musculo-skeletal, cardiovascular and central nervous systems [OIE Terrestrial Manual chapter 3.01.04]. The most rational approach for preventing human brucellosis is the control and elimination of the infection in animals [https://www.who.int/ zoonoses/diseases/brucellosis/en/]. Therefore, it is important to select the main diagnostic antigen of brucellosis and establish a rapid diagnostic method to prevent and treat the disease.

Serology immunological detection technology mainly relies on LPS antigen, however, related studies have shown that LPS antigen has the high cross-reactivity of with several Gram-negative bacteria. Therefore, the LPS antigen is not appropriate for specificity diagnosis of brucellosis [18-20]. In recent years, many researchers are looking for a better diagnostic antigen such as outer membrane proteins (OMPs) to replace LPS to improve the specificity of immunological detection technology [21-24]. OMPs are exposed on the bacterial surface, which may be closely related to the virulence of brucellosis [25]. Lindler et al identified a group of non-LPS immunogens as OMPs, which can be used for vaccine development and brucellosis diagnosis [26]. One of these OMPs, OMP22, has many advantages, such as being

Table 4 Clinical sample detection with ICST and RBPT

\begin{tabular}{llll}
\hline ICTS & RBPT & & Total \\
\cline { 2 - 3 } & Positive & Negative & \\
\hline Positive & 85 & 3 & 88 \\
Negative & 1 & 61 & 62 \\
Total & 86 & 64 & 150 \\
\hline
\end{tabular}


Table $\mathbf{5}$ Sensitivity assay of RBPT testing of brucellosis

\begin{tabular}{ll}
\hline Dilution & Result \\
\hline $1: 2$ & $(+)$ \\
$1: 4$ & $(+)$ \\
$1: 8$ & $(+)$ \\
$1: 16$ & $(+)$ \\
$1: 32$ & $(+)$ \\
$1: 64$ & $(-)$ \\
$1: 128$ & $(-)$ \\
$1: 256$ & $(-)$ \\
\hline
\end{tabular}

highly conserved among all Brucella species and almost identical in amino acid sequence to OMP25. In a previous clinical study, the absence of OMP25 or OMP22 proteins was demonstrated to lead to a striking decrease in the virulence of B. ovis PA in mice [27]. Another OMPs, OMP28, is a conserved protein that presents in at least four Brucella species including B. melitensis, $B$. abortus, B. suis, and B. ovis. The protein has been fully studied and can be used as a vaccine candidate or as an antigen for serological diagnosis [28-30]. The studies showed that the rOMP28-based I-ELISA had high sensitivity and specificity in the diagnosis of brucellosis in bovine sera [31-34]. Lim et al established an ELISA method for detecting bovine brucellosis antibodies by coating rOMP28 antigen. The sensitivity, specificity and accuracy of the method are $96.7,95.4$ and $96.2 \%$, respectively [28]. In our present study, we also used the OMP22 and OMP28 as the diagnostic antigen to test brucellosis antibodies by immunochromatography.

Brucella OMPs are generally expressed in the form of inclusion bodies in E. coli, and the refolding rate of

Table 6 Repeatability of the ICST for brucellosis

\begin{tabular}{|c|c|c|c|c|c|}
\hline \multirow{2}{*}{$\begin{array}{l}\mathrm{C} \\
\text { (ng/ } \\
\mathrm{mL})\end{array}$} & \multicolumn{5}{|l|}{$\mathrm{H}_{\mathrm{T}} / \mathrm{H}_{\mathrm{C}}$} \\
\hline & Repeat1 & Repeat2 & Repeat3 & Mean & CV(\%) \\
\hline 0 & 0.0171 & 0.0175 & 0.0177 & 0.0174 & 1.42 \\
\hline 1 & 0.0478 & 0.0455 & 0.0484 & 0.0472 & 2.65 \\
\hline 5 & 0.0641 & 0.0626 & 0.0697 & 0.0654 & 4.60 \\
\hline 10 & 0.1684 & 0.1661 & 0.1449 & 0.1598 & 6.62 \\
\hline 15 & 0.6964 & 0.6316 & 0.6802 & 0.6694 & 4.11 \\
\hline 20 & 1.1364 & 1.1056 & 1.0006 & 1.0809 & 5.38 \\
\hline 25 & 1.9127 & 1.5876 & 1.7925 & 1.7643 & 7.61 \\
\hline 30 & 1.9263 & 1.7422 & 1.6239 & 1.7641 & 7.05 \\
\hline 35 & 2.0472 & 1.8752 & 2.3045 & 2.0756 & 8.50 \\
\hline 40 & 2.3329 & 2.1006 & 2.1923 & 2.2086 & 4.33 \\
\hline 45 & 2.9876 & 2.5969 & 2.4273 & 2.6706 & 8.78 \\
\hline 50 & 3.0015 & 3.0314 & 3.1425 & 3.0585 & 1.98 \\
\hline
\end{tabular}

inclusion bodies is low, which cannot meet the requirements of this test. Therefore, the pCold-TF DNA vector containing a $48 \mathrm{kD}$ fusion tag was used in this study to express OMP22 and OMP28 in the supernatant in $E$. coli. Considering that the large fusion tag will affect the immunogenicity of the protein, the fusion tag was removed by HRV 3 C Protease. And then the target protein was purified by combining with His-Tag containing medium.

Recently, many researchers have focused on the development of quantum dot fluorescent microspheres (QDFM) immunochromatography, which has been widely used in the field of biological and chemical detection. Compared with other detection technologies, these immunoassay methods have many advantages such as fast detection speed, good efficiency, strong specificity, high sensitivity and simple operation [35]. For example, Taranova et al established a QD-based immunochromatographic analysis method for the detection of several antibiotics in milk [36]. This labelled technology forms hundreds or even thousands of particles by encapsulating or connecting to other materials to form nanoparticles. It has the unique characteristics of good light stability and biocompatibility, long fluorescence lifetime, wide excitation spectrum, narrow emission spectrum and adjustable size. With these advantages, QDFM is expected to become an applied immunolabeling technology [37, 38]. Compared with other labeling technologies, QDFM amplify the light signal of antigen-antibody specific binding and improve the sensitivity $[39,40]$. The method has the advantages of short detection time, no need for sophisticated instruments, simple operation and low cost [41, 42].

QDFM test strips have strict requirements for the immunogenicity of labelled proteins. Dan et al developed a method to detect Brucella by combining QD and magnetic beads with different polyclonal antibodies. The method requires $105 \mathrm{~min}$ and the limit of detection was $10^{3} \mathrm{CFU} / \mathrm{mL}$ [43]. The established method in this study takes only $10-15 \mathrm{~min}$ to obtain the test results and its limit of detection is $1.05 \mathrm{ng} / \mathrm{mL}$. After the coating concentration of the NC membrane was optimized, $\mathrm{H}_{\mathrm{T}} / \mathrm{H}_{\mathrm{C}}$ $(\mathrm{x})$ and sample concentration (y) showed a good correlation (Fig. 2).

As is shown in Table 3, QDMF can be used for Brucella antibodies detection in real samples with high specificity. The test results of Brucella serum samples were positive, while the test results of Yersinia enteritidis O:9, E. coli O:157 and Salmonella Dublin were all negative, indicating that the method has good specificity. As Table 4 shows, ICST shows high feasibility in the 150 clinical serum samples assay and the total coincidence rate of ICST and RBPT was 97.3\%. Compared with RBPT, the positive coincidence rate of ICST was $98.8 \%$ and the 
negative coincidence rate of ICST was $95.3 \%$. This further shows that the detection method can obtain ideal results in the detection of Brucella clinical samples.

\section{Conclusion}

In this study, we presented QDFM tagged OMP22 to facilitate detection of Brucella antibodies in standard and clinical samples of only a few microliters using ICST. The limit of detection was $1.05 \mathrm{ng} / \mathrm{mL}$ (1:512), the total coincidence rate of ICST and RBPT was $97.3 \%$, the positive coincidence rate was $98.8 \%$, the negative coincidence rate was $95.3 \%$, the repeatability was good and the overall average $\mathrm{CV}$ value is $8.78 \%$, the sensitivity of RBPT is $1: 32$ and no cross reaction with the sera of other related diseases was observed. However, the quantitative research of this method needs to be further studied.

\section{Methods}

\section{Materials and reagents}

Quantum dot fluorescent microspheres were purchased from Invitrogen Corp (Carlsbad, CA, USA). A Rose Bengal plate test (RBPT) was obtained from the China Institute of Veterinary Drug Control. Bovine serum albumin (BSA), tween-20, polyvinyl pyrrolidone (PVP), sodium azide, tris base (TB), 2-(4-Morpholino) ethanesulfonic acid (MES), 1-(3-dimethylaminopropyl)-3-ethylcarbodiimide hydrochloride (EDC) and N-hydroxysuccinimide (NHS) were purchased from Sigma Chemical Co. (St. Louis, MO, USA). The test strip materials, including nitrocellulose (NC) membranes (Millipore Hiflow-95) and glass cellulose membranes (Product number 8951), were purchased from Shanghai Jiening Biotechnology Co., Ltd. (Shanghai, China).

\section{Apparatus}

The BioDot XYZ dispensing platform (BioDot, Richmond, CA, USA) was used to dispense reagents to nitrocellulose membrane, conjugate pad and an automatic cutter (BioDot, Richmond, CA, USA) was used to cut the strips. A fluorescent strip reader JN615 was purchased from Shanghai Jie Ning Biological Co., Ltd. (Shanghai, China). A 365-nm hand held UV lamp (American Precision Co., Ltd., USA) was used to test strips.

\section{Samples and biological materials}

Bovine Brucella negative and positive standard sera were purchased from the China Institute of Veterinary Drug Control. Positive sera of Y.enterocolitica O:9(2 goat serum), E.coli O:157(4 bovine serum), Salmonella Dublin (2 sheep serum) and 50 healthy negative bovine and sheep ( 30 bovine serum, 20 sheep serum) were preserved in the Chinese Academy of Inspection and Quarantine.
A total of 150 clinical serum samples (68 bovine serum, 44 sheep and 38 goat serum) were kindly provided by the Animal Husbandry Bureau of Ningxia Hui Autonomous Region (Table 7). Brucella OMP22 and OMP28 and monoclonal antibodies of OMP22 were prepared by our laboratory.

\section{Preparation of QDFM conjugates protein}

The protein is coupled to QDFM through carboxyl activation. Transfer the commercial QDFM solution $(100 \mu \mathrm{L})$ into a centrifuge tube and prepare OMP22QDFM using EDC and NHS as cross-linking agents. The mixture solution was dissolved in MES buffer to produce a final concentration of $0.5 \mathrm{mg} / \mathrm{mL}$ EDC and $0.2 \mathrm{mg} / \mathrm{mL}$ NHS. The solution was vortexed for $30 \mathrm{~min}$ and then reacted at $37^{\circ} \mathrm{Cfor} 15 \mathrm{~min}$. Then, $100 \mu \mathrm{L}$ of OMP22 $(0.1$ $\mathrm{mg} / \mathrm{mL}$ ) was added and the mixture was reacted for 2-4 $\mathrm{h}$ under slow stirring at room temperature. Fifty $\mu \mathrm{L}$ of $10 \%$ BSA was added and the mixture was incubated at room temperature for $30 \mathrm{~min}$. The resulting QDFM conjugate was washed 3 times by centrifugation at $8000 \mathrm{~g}$ for $20 \mathrm{~min}$. The QDFM-OMP22 conjugate was resuspended in $1 \mathrm{~mL}$ of $20 \mathrm{mM}$ Trise solution (TB, pH 8.5) containing $0.5 \%$ BSA, $2 \%$ sucrose, $0.2 \%$ Tween-20, Triton $405-\mathrm{X}$ and kept at $4{ }^{\circ} \mathrm{C}$ until use [44].

\section{Assembly of the QDFM test strip}

The test strip is composed of four parts: sample pad, conjugate pad, nitrocellulose membrane and absorbent pad. The sample pad is soaked in $20 \mathrm{mM} \mathrm{TB}$ ( $\mathrm{pH} 8.5$ ) buffer containing $5 \%$ sucrose, $0.5 \%$ BSA, $0.01 \%$ PVP- 40 , $2 \%$ Tween-20 and $0.02 \% \mathrm{NaN} 3$. And then dried at $70{ }^{\circ} \mathrm{C}$ for $2 \mathrm{~h}$ and stored at room temperature. Paste the test strip components on the PVC backplane in turn and overlap the two components by $2-\mathrm{mm}$ to ensure that the test sample solution can migrate to the entire assembled test strip. In our present study, QDFM labeled Brucella OMP22 was dispensed onto the conjugate pad and then the pad was dried at $37^{\circ} \mathrm{C}$ overnight and stored at $4{ }^{\circ} \mathrm{C}$. $0.03 \mathrm{~mL}$ of OMP28 $(1.5,1,0.75 \mathrm{mg} / \mathrm{mL})$ and $0.03 \mathrm{~mL}$ of McAb OMP22 (1, 0.75, $0.5 \mathrm{mg} / \mathrm{mL})$ were dispensed onto the nitrocellulose membrane as test and control lines, respectively, and the strip was dried at $37^{\circ} \mathrm{C}$ for $2 \mathrm{~h}$. Finally, the whole assembled strip was cut into a $5-\mathrm{mm}$

Table 7 Clinical positive serum sample background

\begin{tabular}{lll}
\hline ID & Animal species & species \\
\hline A1-A39 & bovine & B. abortus \\
B1-B23 & goat & B. melitensis \\
C1-C26 & sheep & B.ovis \\
D1-D29 & bovine & $/$ \\
E1-E15 & goat & $/$ \\
F1-F18 & sheep & $/$ \\
\hline
\end{tabular}




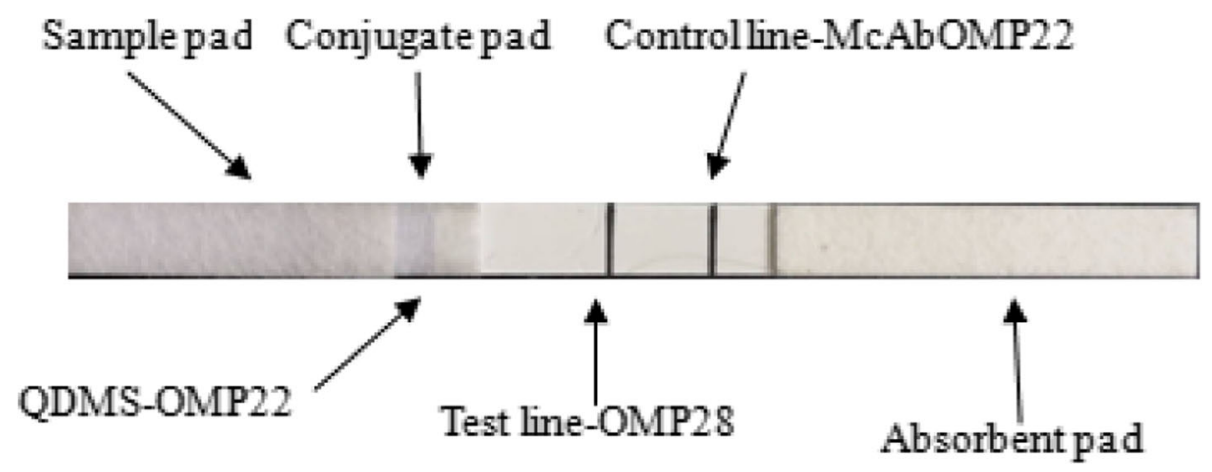

Fig. 3 Schematic diagram of the QDFM based multiplex ICST. The control line was coated with MCAb against OMP22 and the test lines was coated with OMP28. The conjugate pad was QDFM functional OMP22

width and 80-mm length using a BIO-DOT strip cutting machine (Fig. 3). Eight brucellosis positive serum samples with different concentrations were tested to determine the NC membrane coating concentrations. The corresponding concentrations of the samples were 0.169 $\mathrm{ng} / \mu \mathrm{L}, 0.666 \mathrm{ng} / \mu \mathrm{L}, 1.35 \mathrm{ng} / \mu \mathrm{L}, 2.11 \mathrm{ng} / \mu \mathrm{L}, 3.06 \mathrm{ng} / \mu \mathrm{L}$, $27.06 \mathrm{ng} / \mu \mathrm{L}, 45.2 \mathrm{ng} / \mu \mathrm{L}, 64.2 \mathrm{ng} / \mu \mathrm{L}$, respectively.

According to the three detection antibody analysis protocols described by Sotnikov et al our research plan is similar to the author's second protocol. The extramembrane protein OMP22 binds to the antibody in the serum sample and is captured by OMP28 on the detection line to form an OMP22-Ab-OMP28 immune complex [45].

\section{Sensitivity, threshold, specificity, feasibility and repeatability test}

The standard cure was established with serial 2-fold dilutions of Brucella positive serum from 1:4 to 1:1024 and ICST was used determine the limit of detection.

Fifty healthy bovine and sheep serum samples were tested as negative controls to determine the threshold of results. The $365 \mathrm{~nm}$ handheld UV lamp is used to initially observe the results of the test strip, and then use a fluorescence reader to record the ratio of the test line signal to the control line signal $\left(\mathrm{H}_{\mathrm{T}} / \mathrm{H}_{\mathrm{C}}\right)$. Calculate the $\mathrm{H}_{\mathrm{T}} / \mathrm{H}_{\mathrm{C}}$ threshold of ICST by the following formula: Threshold $=$ average $\pm 3 \times$ standard deviation.

ICST was used to detect Yersinia enteritidis O: 9, E. coli O: 157 and Salmonella Dublin positive serum samples and the results were recorded with a fluorescence reader. According to the size of the threshold to determine the specificity of the test strips.

In order to evaluate the feasibility of the test strip for detecting brucellosis antibodies, 150 clinical serum samples of brucellosis were collected from the Animal Husbandry Bureau of Ningxia Hui Autonomous Region. All samples were pretreated with $0.01 \mathrm{M}$ Tris- $\mathrm{HCl}(\mathrm{pH}$ 9.5) buffer containing $0.9 \% \mathrm{NaCl}$ and $0.05 \%$ Tween-20 for $15 \mathrm{~min}$. One hundred fifty clinical samples were tested using ICST and the coefficients of the test results were compared with commercial RBPT. Serial 2-fold dilution of bovine Brucella positive standard sera from 1:2 to 1: 256 were used in order to determine the sensitivity of RBPT [46].

The repeatability of ICST was tested by 11 serially diluted standard brucellosis positive serum samples concentrations ranging from $50 \mathrm{ng} / \mathrm{mL}$ to $1 \mathrm{ng} / \mathrm{mL}$ and 1 negative serum. Each sample was detected for three times to calculated coefficient of variation (CV). The CV was calculated by dividing the mean of three measurements by the standard deviation to determine the repeatability.

\section{Abbreviations}

ICST: Immunochromatographic strip test; RBPT: Rose Bengal plate test; QDFM: Quantum dot fluorescent microspheres; SAT: Standard tube agglutination test; ELISA: Enzyme-linked immunosorbent assay; SLPS: Smooth lipopolysaccharides; PCR: Polymerase chain reaction; qPCR: Real time PCR; OMPs: Outer membrane proteins; TB: Tris base; NC: Nitrocellulose; MES: 2-(4-Morpholino) ethanesulfonic acid; EDC: 1-(3-dimethylaminopropyl)3-ethylcarbodiimide hydrochloride; NHS: N-hydroxysuccinimide; BSA: Bovine serum albumin; CV: Coefficient of variation; PVP: Polyvinyl pyrrolidone

\section{Acknowledgements}

We are grateful to all the members of the Laboratory of Institute of Animal Quarantine, Chinese Academy of Inspection and Quarantine for their helpful discussions, encouragements, and support.

\section{Authors' contributions}

YFK and HYW collected and analyzed data and drafted the first version of the manuscript. SQW, JZL, LM and HFZ performed experiments and analyzed the data. XML and XQH participated in the conception and design the experiments and critically revised the manuscripts. All authors read and approved the final manuscript.

\section{Funding}

This work was financed by the National Key Research and Development Program of China (2017YFD0501803) and the Research Program of Chinese Academy of Inspection and Quarantine (2018JK012). The funding sources had no involvement in the design of the research, the collection, analysis, and interpretation of data, and the writing of the manuscript. 


\section{Availability of data and materials}

The data sets used and/or analyzed during the current study are available from the corresponding author on reasonable request.

\section{Ethics approval and consent to participate}

This article does not contain any studies with humans. All animal experiments in this study were approved and conducted under the supervision by Ethics Committee on Scientific Research on Animal Pathogenic Microorganisms, Institute of Animal Quarantine, Chinese Academy of Inspection and Quarantine (ECSRAPM0626001). Orally permissions were obtained from the owners before collection of the specimens. Ethics Committee on Scientific Reseach on Animal Pathogenic Microorganisms (ECSRAPM) approved the procedure for verbal consent. ECSRAPM felt the need for written consent was not necessary for this study.

\section{Consent for publication}

Not applicable.

\section{Competing interests}

The authors declare that they have no competing interests.

\section{Author details}

${ }^{1}$ Institute of Animal Inspection and Quarantine Chinese Academy of Inspection and Quarantine 100176 Beijing China . ${ }^{2}$ People's Hospital of Jiaxiang, Jiaxiang County, Jining City 272400, Shandong Province, China.

Received: 23 June 2020 Accepted: 12 January 2021

Published online: 23 January 2021

\section{References}

1. Pappas G, Papadimitriou P, Akritidis N, Christou L, Tsianos EV. The new global map of human brucellosis. Lancet Infect Dis. 2006;6:91-9.

2. Godfroid J, Cloeckaert A, Liautard JP, Kohler S, Fretin D, Walravens K, GarinBastuji B, Letesson JJ. From the discovery of the Malta fever's agent to discovery of a marine mammal reservoir, brucellosis has continuously been a re-emerging zoonosis. Vet Res. 2005;36:313-36.

3. Zinsstag J, Roth F, Orkhon D, Chimed-Ochir G, Nansalmaa M, Kolar J, Vounatsou P. A model of animal-human brucellosis transmission in Mongolia. Prev Vet Med. 2005;69:77-95.

4. Falenski A, Mayer-Scholl A, Filter M, Göllner C, Appel B, Nöckler K. Survival of Brucella spp. in mineral water, milk and yogurt. Int J Food Microbiol. 2011;145: 326-30.

5. Franco MP, Mulder M, Gilman RH, Smits HL. Human brucellosis. Lancet Infect Dis. 2007;7:775-86

6. de Oliveira MZ, Vale V, Keid L, Freire SM, Meyer R, Portela RW, Barrouin-Melo SM. Validation of an ELISA method for the serological diagnosis of canine brucellosis due to Brucella canis. Res Vet Sci. 2011;90(3):425-31.

7. Li L, Yin D, Xu K, Liu Y, Song D, Wang J, Zhao C, Song X, Li J. A sandwich immunoassay for brucellosis diagnosis based on immunemagnetic beads and quantum dots. J Pharmaceut Biomed. 2017;141:79-86.

8. Patra KP, Saito M, Atluri VL, Rolán HG, Young B, Kerrinnes T, Smits H, Ricaldi JN, Gotuzzo E, Gilman RH, Tsolis RM, Vinetz JM. A protein-conjugate approach to develop a monoclonal antibody-based antigen detection test for the diagnosis of human brucellosis. PLoS Negl Trop Dis. 2014;6(8):1-13.

9. Ahmed IM, Khairani-Bejo S, Hassan L, Bahaman AR, Omar AR. Serological diagnostic potential of recombinant outer membrane protein (rOMPs) from Brucella melitensis in mouse model using indirect enzyme-linked immunosorbent assay. BMC Vet Res. 2015;11:275.

10. Corrente M, Desario C, Parisi A, Grandolfo E, Scaltrito D, Vesco G, Colao V, Buonavoglia D. Serological diagnosis of bovine brucellosis using melitensis strain B115. J Microbiol Methods. 2015;119:106-9.

11. Gupta VK, Shivasharanappa N, Kumar V. Diagnosis evaluation of serological assays and different gene based PCR for detection of Brucella melitensis in goat. Small Rumin Res. 2014;117:94-102.

12. Orzil LD, Preis IS, de Almida IG, de Souza PG, Soares PM, Jacinto FB, Fonseca AA. Validation of the multiplex PCR for identification of Brucella spp. Cienc Rural. 2016;5(46):847-52.

13. Tabibnejad M, Alikhani MY, Arjomandzadegan M, Hashemi SH, Naseri Z. The optimization of molecular detection of clinical isolates of Brucella in blood cultures by eryD transcriptase gene for confirmation of culture-negative samples. Iran Red Crescent Med J. 2016;18(4):e23879.
14. Dmitriy VS, Nadezhda AB, Anatoly VZ, Saule ZE, Kairat KB, Kasim KM, Erlan MR, Elchin GS, Boris BD. Express immunochromatographic detection of antibodies against Brucella abortus in cattle sera based on quantitative photometric registration and modulated cut-off level. J Immunoassay Immunochem. 2015;36:80-90.

15. Song C, Zhi A, Liu Q, Yang J, Jia G, Shervin J, Tang L, Hu X, Deng R, Xu C, Zhang G. Rapid and sensitive detection of beta-agonists using a portable fluorescence biosensor based on fluorescent nanosilica and a lateral flow test strip. Biosens Bioelectron. 2013;50:62-5.

16. Xu W, Chen X, Huang X, Yang W, Liu C, Lai W, Xu H, Xiong Y. Ru (phen) 3 (2+) doped silica nanoparticle based immunochromatographic strip for rapid quantitative detection of beta-agonist residues in swine urine. Talanta. 2013;114: 160-6.

17. McGiven JA. New developments in the immunodiagnosis of brucellosis in livestock and wildlife. Rev Sci Tech. 2013;32(1):163-76.

18. Nielsen K, Smith P, Yu WL, Halbert G. Salmonella enterica serotype Urbana interference with brucellosis serology. J Immunoassay Immunochem. 2007;28: 289-96.

19. Vahedi F, Talebi AF, Ghorbani E, Behroozikhah AM, Ahmadi FS. Isolation, cloning and expression of the Brucella melitensis OMP31 gene. Iran J Vet Res. 2011:12:156-62.

20. Weynants V, Tibor A, Denoel PA, Saegerman C, Godfroid J, Thiange P, Letesson JJ. Infection of cattle with Yersinia enterocolitica O:9 a cause of the false positive serological reactions in bovine brucellosis diagnostic tests. Vet Microbiol. 1996;48:101-12.

21. Büyüktanir Ö, Genç O, Yurdusev N. Production, purification and characterization of the recombinant Brucella abortus rP17 protein. Kafkas Univ Vet Fak. 2011;17:135-40.

22. Farahi F, Asli E, Mobarez AM, et al. Recombinant Brucella abortus outer membrane protein 19 (rOMP19) significantly stimulates splenic lymphocytes of immunized BALB/c mice. Afr J Microbiol Res. 2012;6:4128-31.

23. Thavaselvam D, Kumar A, Tiwari S, Mishra M, Prakash A. Cloning and expression of the immunoreactive Brucella melitensis $28 \mathrm{kDa}$ outermembrane protein (OMP28) encoding gene and evaluation of the potential of OMP28 for clinical diagnosis of brucellosis. J Med Microbiol. 2010;59:421-8.

24. Eoh H, Jeon BY, Kim Z, Kim SC, Cho SN. Expression and validation of Derythrulose 1-phosphate dehydrogenase from Brucella abortus: a diagnostic reagent for bovine brucellosis. J Vet Diagn Investig. 2010;22:524-30.

25. Martín-Martín Al, Caro-Hernández P, Orduña A, Vizcaíno N, Fernández-Lago L. Importance of the Omp25/Omp31 family in the internalization,and intracellular replication of virulent B. ovis in murine macrophages and HeLa cells. Microbes Infect. 2008;10(6):706-10.

26. Lindler $L E$, Hadfield $T L$, Tall BD, Snellings NJ, Rubin FA, Van De Verg LL, Hoover D, Warren RL. Cloning of a Brucella melitensis group 3 antigen gene encoding Omp28, a protein recognized by the humoral immune response during human brucellosis. Infect Immun. 1996;64:2490-9.

27. Caro-Hernández P, Fernández-Lago L, de Miguel MJ, Martín-Martín Al, Cloeckaert A, Grilló MJ, Vizcaíno N. Role of the Omp25/Omp31 family in outer membrane properties and virulence of Brucella ovis. Infect Immun. 2007;75(8):4050-61.

28. Lim JJ, Kim DH, Lee JJ, Kim DG, Min W, Lee HJ, Rhee MH, Chang HH, Kim S. Evaluation of recombinant $28 \mathrm{kDa}$ outer membrane protein of Brucella abortus for the clinical diagnosis of bovine brucellosis in Korea. J Vet Med Sci. 2012;74(6):687-91.

29. Chaudhuri P, Prasad R, Kumar V, Gangaplara A. Recombinant Omp28 antigen based indirect ELISA for serodiagnosis of bovine brucellosis. Mol Cell Probes. 2010;24:142-5.

30. Patricia SM, JeanM V, Maggy G, Axel C, Clara MM, Michel SZ, Luis FL, Nieves V. Epitope Mapping of the Brucella melitensis BP26 Immunogenic Protein: Usefulness for Diagnosis of Sheep Brucellosis. Clin Diagn Lab Immunol. 2003;10(4):647-51.

31. Manat Y, Shustov AV, Evtehova E, Eskendirova SZ. Expression, purification and immunochemical characterization of recombinant OMP28 protein of Brucella species. Open Vet J. 2016;6(2):71-7.

32. Cloeckaert A, Baucheron S, Vizcaino N, Zygmunt MS. Use of recombinant BP26 protein in serological diagnosis of Brucella melitensis infection in sheep. Clin Diagn Lab Immunol. 2001;8(4):772-5.

33. Liu WX, Hu S, Qiao ZJ, Chen WY, Liu LT, Wang FK, Hua RH, Bu ZG, Li XR. Expression, purification, and improved antigenic specificity of a truncated recombinant bp26 protein of Brucella melitensis M5-90: a potential antigen 
for differential serodiagnosis of brucellosis in sheep and goats. Biotechnol Appl Biochem. 2011;58(1):32-8.

34. Cha SB, Rayamajhi N, Lee WJ, Shin MK, Jung MH, Shin SW, Kim JW, Yoo HS Generation and envelope protein analysis of internalization defective Brucella abortus mutants in professional phagocytes, RAW 264.7. FEMS Immunol Med Microbiol. 2012;64(2):244-54.

35. Yang Q, Gong X, Song T, Yang J, Zhu S, Li Y, Cui Y, Li Y, Zhang B, Chang J. Quantum dot-based immunochromatography test strip for rapid, quantitative and sensitive detection of alpha fetoprotein. Biosens Bioelectron. 2011;30:145-50.

36. Taranova NA, Berlina AN, Zherdev AV, Dzantiev BB. 'Traffic light' immunochromatographic test based on multicolor quantum dots for the simultaneous detection of several antibiotics in milk. Biosens Bioelectron. 2014;63:255-61.

37. Di Nardo F, Anfossi L, Giovannoli C, Passini C, Goftman W, Goryacheva IY, Baggiani C. A fluorescent immunochromatographic strip test using quantum dots for fumonisins detection. Talanta. 2016;150:463-8

38. Xie Y, Zhang L, Yang X, Le T. Development of a quantum dot-based immunochromatography test strip for rapid screening of oxytetracycline and 4-epioxytetracycline in edible animal tissues. Food Addit Contam A. 2017;34(3):371-8.

39. Qiu L, Bi Y, Wang C, Li J, Guo P, Li J, He W, Wang J, Jiang P. Protein a detection based on quantum dots antibody bioprobe using fluorescence coupled capillary electrophoresis. Int J Mol Sci. 2014;15(2):1804-11.

40. Mulder WJ, Castermans K, van Beijnum JR, Oude Egbrink MG, Chin PT, Fayad ZA, Löwik CW, Kaijzel EL, Que I, Storm G, Strijkers GJ, Griffioen AW, Nicolay K. Molecular imaging of tumor angiogenesis using alphavbeta3integrin targeted timodal quantum dots. Angiogenesis. 2009;12(1):17-24.

41. Zhu MY, Tang YJ, Wen QQ, Li J, Yang PH. Dynamic evaluation of cellsecreted interferon gamma in response to drug stimulation via a sensitive electro-chemiluminescence immnosensor based on a glassy carbon electrode modified with graphene oxide, polyaniline nanofibers, magnetic beads, and gold nanoparticles. Microchim Acta. 2016;183:1739-48.

42. Min H, Jo SM, Kim HS. Efficient capture and simple quantification of circulating tumor cells using quantum dots and magnetic beads. Circ Tumor Cells. 2015;21(11):2536-42.

43. Song D, Qu X, Liu Y, Li L, Yin D, Li J, Xu K, Xie R, Zhai Y, Zhang H, Bao H, Zhao C, Wang J, Song X, Song W. A rapid detection method of Brucella with quantum dots and magnetic beads conjugated with different polyclonal antibodies. Nanoscale Res Lett. 2017;12:179.

44. Le T, Zhang Z, Wu J, Shi H, Cao X. A fluorescent immunochromatographic strip test using a quantum dot-antibody probe for rapid and quantitative detection of 1-aminohydantoin in edible animal tissues. Anal Bioanal Chem. 2018:410(2):565-72.

45. Dmitriy VR, Anna NB, Anatoly VZ, Saule ZE, Kassym KM, Yerlan MR, Kannatbek NM, Boris BD. Comparison of three schemes of quantum dotsbased Immunochromatography for Serodiagnosis of brucellosis in cattle J. Eng Appl Sci. 2019;14(11):3711-8.

46. McGiven J, Taylor A, Duncombe L, Sayers R, Albert D, Banai M, Blasco JM, Elena S, Fretin D, Garin-Bastuji B, Melzer F, Muñoz PM, Nielsen K, Nicola A, Scacchia M, Tittarelli M, Dias IT, Walravens K, Stack J. The first international standard anti-Brucella melitensis serum. Rev Sci Tech. 2011;30(3):809-19.

\section{Publisher's Note}

Springer Nature remains neutral with regard to jurisdictional claims in published maps and institutional affiliations.

Ready to submit your research? Choose BMC and benefit from:

- fast, convenient online submission

- thorough peer review by experienced researchers in your field

- rapid publication on acceptance

- support for research data, including large and complex data types

- gold Open Access which fosters wider collaboration and increased citations

- maximum visibility for your research: over $100 \mathrm{M}$ website views per year

At BMC, research is always in progress.

Learn more biomedcentral.com/submissions 